earthquake and subsequent fires, the sea-waves were responsible for the greater part. In the Iwaki prefecture, that immediately to the west of the epicentre, the sea-waves advanced in the form of a wall of water from four to seven feet in height, that swept away villages along the coast and wrecked several small towns, At Kamaishi, the sea-wall was broken down by the waves and 1,500 houses were destroyed.

The loss of life and the injury to property were considerable. According to official figures issued on March 5, 1,560 persons were killed, 956 are missing and 354 wounded; while 2,878 houses were washed away, 1,458 were thrown down, and 211 burned.

One of the most notable predecessors of the recent earthquake was that which occurred on June 15, 1896, and is known as the Sanriku earthquake. According to Omori and Hirata $(J$. Coll. Sci., Tokyo Imp. Univ., vol. 11, pp. 161-195; 1899 ), its epicentre lay in lat. $39^{\circ} \mathrm{N}$., long. $144 \frac{1}{2}^{\circ} \mathrm{E}$., or some miles to the south of that of the recent earthquake.

In Japan, as elsewhere, great earthquakes seldom visit the same region, except at long intervals of time. The centres of successive earth- quakes belonging to the same seismic zone are rather displaced some or many miles-in this case perhaps sixty miles-along that zone. On land, the Sanriku earthquake was much less violent than the recent shock, though it was felt to a distance of 320 miles from its centre, but it was followed by far greater sea-waves. All eyeestimates of the height of sea-waves are subject to large errors, and we cannot have much confidence in such figures as $94 \mathrm{ft}$. at Yoshihama and $60 \mathrm{ft}$. or $100 \mathrm{ft}$. along the eastern coast of Hokkaido. At Ayukawa, however, which is 170 miles from the epicentre, the tide-gauge showed for the chief movement a rise of $8 \mathrm{ft}$. above the usual level, followed by a fall of the same amount below it. The waves were certainly large enough to be recorded at Honolulu and Sausalito, at the entrance to San Francisco Bay, the latter station being 4,787 miles from the epicentre.

In 1896, the sea-waves were far more destructive to life and property than those of the present year. In Kamaishi, 4,700 of the 6,557 inhabitants were drowned and 88 per cent of the houses were swept away. Along the whole coast affected, the number of lives lost amounted to 28,321, and of houses ruined to 6,222 .

\title{
Obituary
}

LORD LOVAT, K.T., G.C.V.o., K.C.M.G.

T HE death of Lord Lovat on February 18 will prove a great loss to forestry both in Great Britain and throughout the Empire. To his strong personality, tireless energy and great grasp of detail, Great Britain owes it to-day that she has a Forestry Commission in being, a considerable addition to the afforested area, and, it may be justifiably hoped, a settled forest policy. In future years it may come to be recognised that Lord Lovat's greatest claim to remembrance by his fellow countrymen will be the great part he played in a resuscitation of the national forestry question, which had practically lain dormant for more than a century.

Lord Lovat's interest in forestry, from a wider point of view than his own estates, was aroused before the War. In the latter part of the great struggle he acted as Director of Forestry in France, to co-ordinate the forestry operations being carried out with the object of supplying the troops in the field with the essential timber and other products of the forests. During this period, he was one of the originators of the Acland Report drawn up as a result of the Departmental inquiry, 1916-17, with the object of pressing upon the Government the paramount necessity of taking up the question of afforestation in Britain at the close of hostilities.

A Forestry Bill to this end was presented to Parliament and passed in 1919 and Lord Lovat was appointed in 1920 chairman of the Forestry Commission, which was empowered to carry out the provisions of the Bill. With the object of leaving the new Commission free from politics, a Treasury allotment was made and the Commission was not placed under a minister of the Crown.

With that energy and vitality for which he was renowned, Lord Lovat at once devoted himself to this new business, which involved commencing a planting campaign on land to be obtained from private individuals, since no State-owned land existed. That the organisation he and his Commissioners introduced was effective is proved by the fact that when he resigned the chairmanship in 1927 some 94,289 acres had been afforested and 391,511 acres of land had been acquired by the State. Before he resigned his post, with the spirit of generosity which animated him, he stated publicly: "If any good work has been done by the Forestry Commission, it does not lie with me but with the excellent body of Commissioners and staff which we have in the Forestry Commission." Yet it was an open secret that, but for Lord Lovat, the 'Geddes axe' might have brought the work of the Forestry Commissioners to an abrupt end and that on several occasions serious changes in policy were only prevented by his influence and tact.

Lord Lovat was chairman of the first Empire Forestry Conference, held in London in 1920 after the formation of the Commission, and of the second held in Canada in 1923, during which he visited most of the forests in the Dominion.

In connexion with forestry education and research, Lord Lovat held strong views which 
were not always in accordance with those of the universities as a whole. As a result of the Conference in Canada, he was able to give effect to his scheme of establishing an Imperial Forestry Institute at Oxford with the support of grants from the Colcnial Office in London and grants from certain Dominions and Colonies. The position which the Institute has taken in the eyes of the Empire justifies Lord Lovat's prescience in this matter. He was also responsible in no small degree for the revival of scientific research in forestry problems.

In 1927 Lord Lovat became Parliamentary Under Secretary of State for Dominion Affairs and chairman of the Overseas Settlement Committee. He was also chairman of the Committees on Agriculture in the Colonies and on Colonial Veterinary Sciences. These positions he resigned in 1929 .

From 1927 until his death, Lord Lovat maintained his keen interest in the forestry question in Great Britain and linked to it the broader one of Empire forestry and Empire timber marketing and development as a whole. It is perhaps not too much to say that, outside India, the position of forestry throughout the Empire and the appreciation, which is now making headway at headquarters in London and elsewhere, is due to the vital force which Lord Lovat's invigorating personality gave to it.

E. P. Stebbing.

\section{Prof. Max Wolf}

Prof. Max WoLf died on October 3, at the age of sixty-eight years. He was the son of a physician at Heidelberg, and showed an aptitude for astronomy from his youth. While still at school he erected a small observatory, with an equatorial built by himself; in 1884 he discovered the interesting short-period comet that bears his name.

Wolf soon adopted photographic methods and made the first photographic discovery of a minor planet in 1891. He and his assistants afterwards added many hundreds more. The first discovery was afterwards named Brucia, in appreciation of the gift of a double camera by Miss Wolfe-Bruce. He was appointed a supernumerary professor at Heidelberg in 1893, and succeeded to the ordinary professorship in 1902. He devoted himself to photography of the nebulæ and their spectra, and was the first to detect the expanding nebula round Nova Persei in 1901; he found evidence of rotation in the nebula Messier 81, and discovered the extended nebulosity that surrounds the Pleiades.

Prof. Wolf was one of the first to use the stereoscopic method for detecting proper motions of stars, by comparison of plates taken some years apart. He published several lists of stars with large proper motions. An article by $\mathrm{H}$. Vogt in Astronomische Nachrichten, No. 5921, pays tribute to the excellence of his teaching at Heidelberg, and his popularity.

$\mathrm{He}$ received the gold medal of the Royal Astronomical Society, and similar honours from many other countries. In spite of failing health, he continued at work until the last, and made several planetary discoveries in 1932.

$$
\text { A. C. D. C. }
$$

WE regret to announce the following deaths:

Prof. Carl E. Correns, director of the KaiserWilhelm Institut für Biologie at Berlin-Dahlem, Darwin medallist in 1932 of the Royal Society, on February 15, aged sixty-nine years.

Prof. E. E. Haskell, emeritus professor of experimental hydraulics in Cornell University, and dean of the College of Civil Engineering at the University in 1906-21, on January 28, aged seventy-seven years.

Dr. H. L. Snape, lately chairman of the Association of Directors and Secretaries of Education of the Union of Lancashire and Cheshire Educational Institutes, formerly professor of chemistry at University College, Aberystwyth, on March 2, aged seventy-one years.

Dr. Victor Sterki, assistant curator of Mollusca in the Carnegie Museum, Pittsburgh, since 1909, who has done much work on the anatomy, systematics and distribution of Mollusca, etc., on January 25, aged eighty-six years.

\section{News and Views}

Recommendations for Election to the Royal Society

THE Council of the Royal Society has agreed to recommend for election into the Society the following seventeen candidates : Mr. P. M. S. Blackett, lecturer in physics in the University of Cambridge; Prof. J. B. Collip, professor of biochemistry in McGill University, Montreal ; Col. R. E. B. Crompton, electrical engineer; Prof. H. M. Dawson, professor of physical chemistry in the University of Leeds; Dr. A. T. Doodson, associate director of Liverpool Observatory and Tidal Institute; Dr. H. J. Gough, superintendent of the Engineering Department of the National Physical Laboratory, Teddington; Mr. J. Hammond, senior assistant at the Animal Nutrition
Research Institute, Cambridge ; Dr. G. M. Holmes, physician to the National Hospital for Nervous Diseases, Queen Square, London; Dr. H. King, chemist at the National Institute for Medical Research, Hampstead ; Prof. J. E. Lennard-Jones, Plummer professor of theoretical chemistry in the University of Cambridge; Prof. J. W. McLeod, professor of bacteriology in the University of Leeds ; Dr. A. S. Parkes, physiologist, Foulerton student of the Royal Society; Prof. E. J. Salisbury, Quain professor of botany at University College, London; Dr. B. Smith, district geologist of H.M. Geological Survey; Dr. W. R. Thompson, superintendent of Farnham House Laboratory of the Imperial Institute 